\title{
The Mechanism of the Osteoprotective Action of a Polyphenol-Rich Aronia melanocarpa Extract during Chronic Exposure to Cadmium is Mediated by the Oxidative Defense System
}

Authors

Affiliations
Malgorzata M. Brzóska' ${ }^{1}$, Joanna Rogalska ${ }^{1}$, Alicja Roszczenko ${ }^{1}$, Malgorzata Galazyn-Sidorczuk ${ }^{1}$, Michal Tomczyk ${ }^{2}$

${ }^{1}$ Department of Toxicology, Medical University of Bialystok, Bialystok, Poland

2 Department of Pharmacognosy, Medical University of Bialystok, Bialystok, Poland
Key words

- Aronia melanocarpa

- Rosaceae

- cadmium

polyphenol-rich chokeberry extract

- bone tissue

oxidative/antioxidative status

- oxidative damage

- protection received Sep. 14, 2015

revised February 9, 2016

accepted February 12, 2016

\section{Bibliography}

DOI http://dx.doi.org/

10.1055/s-0042-103593

Published online April 20, 2016

Planta Med 2016; 82: 621-631

(c) Georg Thieme Verlag KG

Stuttgart · New York .

ISSN 0032-0943

\section{Correspondence}

Assoc. Prof. Malgorzata M.

\section{Brzóska, Ph. D.}

Department of Toxicology

Medical University of Bialystok

Adama Mickiewicza 2C Street

15-222 Bialystok

Poland

Phone: + 48857485604

Fax: +48857485834

malgorzata.brzoska@umb.edu.pl

\section{Abstract}

$\nabla$

Recently, we demonstrated in a rat model that consumption of a polyphenol-rich extract obtained from the berries of Aronia melanocarpa could protect from cadmium-induced disorders in bone turnover and changes in bone mineral status. The aim of this study was to investigate whether the osteoprotective effect of this extract is mediated by the oxidative defense system. Enzymatic and nonenzymatic antioxidants, total antioxidative and oxidative status, hydrogen peroxide, and markers of oxidative protein, lipid, and DNA damage were determined in bone tissue at the distal femoral epiphysis of female Wistar rats receiving $0.1 \%$ aqueous $A$. melanocarpa extract (prepared from the lyophilized commercial extract containing $65.74 \%$ of polyphenols) as the only drinking fluid and/or cadmium in the diet (1 and $5 \mathrm{mg} / \mathrm{kg}$ ) for $3,10,17$, and 24 months. The total oxidative and antioxidative status of the serum was also evaluated. The administration of A. melanocarpa extract provided significant protection from cadmium-induced oxidative stress in the bone and serum, and from lipid peroxidation and oxidative damage to the protein and DNA in the bone tissue. Numerous correlations were noted between indices of the oxidative/antioxidative bone status and markers of bone metabolism previously assayed in the animals receiving A. melanocarpa extract. The results allow the conclusion that the ability of $A$. melanocarpa extract to mediate the oxidative defense system and prevent oxidative modifications of protein, lipid, and DNA in the bone tissue plays an important role in its osteoprotective action under exposure to cadmium. The findings provide further evidence supporting our suggestion that chokeberry may be a promising natural agent for protection against the toxic action of cadmium in women chronically exposed to this metal.

\begin{tabular}{|c|c|}
\hline \multicolumn{2}{|c|}{ Abbreviations } \\
\hline ALP: & alkaline phosphatase \\
\hline AME: & $\begin{array}{l}\text { extract from the berries of Aronia } \\
\text { melanocarpa }\end{array}$ \\
\hline BMD: & bone mineral density \\
\hline Ca/AW: & $\begin{array}{l}\text { the ratio of calcium content in } \\
\text { bone and the bone ash weight }\end{array}$ \\
\hline $\mathrm{Ca} / \mathrm{DW}:$ & $\begin{array}{l}\text { the ratio of calcium content in } \\
\text { bone and the bone dry weight }\end{array}$ \\
\hline CAT: & catalase \\
\hline CTX: & $\begin{array}{l}\text { carboxy-terminal cross-linking } \\
\text { telopeptides of type I collagen }\end{array}$ \\
\hline GPx: & glutathione peroxidase \\
\hline GR: & glutathione reductase \\
\hline GSH: & reduced glutathione \\
\hline LPO: & lipid peroxides \\
\hline OC: & osteocalcin \\
\hline OPG: & osteoprotegerin \\
\hline OSI: & oxidative stress index \\
\hline PC: & protein carbonyl groups \\
\hline RANK: & $\begin{array}{l}\text { receptor activator of nuclear } \\
\text { factor-kB }\end{array}$ \\
\hline RANKL: & $\begin{array}{l}\text { receptor activator of nuclear } \\
\text { factor-кB ligand }\end{array}$ \\
\hline ROS: & reactive oxygen species \\
\hline SRANKL: & $\begin{array}{l}\text { soluble receptor activator of } \\
\text { nuclear factor- } k \text { B ligand }\end{array}$ \\
\hline SRANKL/C & the ratio of sRANKL and OPG \\
\hline SOD: & superoxide dismutase \\
\hline TAS: & total antioxidative status \\
\hline TOS: & total oxidative status \\
\hline T-SH: & total thiol groups \\
\hline$\%$ minera & $\begin{array}{l}\text { percentage content of minera } \\
\text { components in bone tissue }\end{array}$ \\
\hline 8-isoP: & 8-isoprostanes \\
\hline 8-OHdG: & 8-hydroxy-2'-deoxyguanosine \\
\hline
\end{tabular}

Supporting information available online at http://www.thieme-connect.de/products 


\section{Introduction}

$\nabla$

Recently, the possibility of using natural plant ingredients for protection against the dangerous action of xenobiotics to which humans are exposed throughout their lifetime, including $\mathrm{Cd}$, which is one of the most toxic heavy metals, has been of special interest to researchers [1-9]. Evidence that even relatively low exposure to $\mathrm{Cd}$ contributes to osteoporosis and bone fractures [10-12] together with forecasts that the general population's exposure to this element will increase [2] are reasons that growing attention has been focused on searching for an effective means of protection from the unfavorable action of this xenobiotic, including damage to the skeleton.

It seems that polyphenols, being the most abundant bioactive components in our diet $[13,14]$, are a promising group of compounds playing a role in this protection $[3-9,15]$. Owing to the large number of -OH groups, these compounds are capable of chelating metal ions, including $\mathrm{Cd}^{2+}[4,6,14]$. It has been revealed that some food products abundant in polyphenolic compounds, including especially green tea and soybeans, may offer protection against various effects of exposure to $\mathrm{Cd}$; however, the data is very sparse and refers only to chosen compounds [3,5-9,15-17]. One of the richest sources of polyphenols is the chokeberry [Aronia melanocarpa (Michx.) Elliott; Rosaceae]. Nowadays, the consumption of aronia berries is widely recommended as one of the most abundant sources of compounds having a beneficial influence on the organism, and the richest source among plant materials of anthocyanins, which are characterized by strong antioxidative properties $[13,14,18-21]$. Data provided by Kowalczyk et al. [15] and our recent findings [6,22,23] seem to indicate that the consumption of chokeberries and their products may prevent $\mathrm{Cd}$ accumulation in the body and its toxic action. Using a female rat model of low and moderate lifetime human exposure to Cd (1 and $5 \mathrm{mg} \mathrm{Cd} / \mathrm{kg}$ diets, respectively, for up to 24 months), we have revealed that a polyphenol-rich AME may decrease the gastrointestinal absorption and body burden of this xenobiotic (including its accumulation in the liver, kidneys, and bone tissue) [22], as well as significantly prevent disturbances induced by this heavy metal in the bone turnover, and changes in the bone mineral status [23].

Taking into account the pro-oxidative action of $\mathrm{Cd}$ and oxidative stress involvement in the mechanisms of this metal's toxicity, including osteotoxic action [3,5,24-28], and the strong antioxidative properties of chokeberry $[13,14,18-20]$, we have hypothesized that the osteoprotective effect reported by us [23] of AME during chronic exposure to Cd may be mediated by the oxidative defense system (the system of defense from oxidative processes and oxidative stress). The aim of the present paper was to investigate this hypothesis. For this purpose, numerous indices of the oxidative/antioxidative bone status and markers of oxidative protein, lipid, and DNA damage were determined in the bone tissue, and mutual dependences between these parameters, indices of bone turnover (Table 1S, Supporting Information), and bone mineral status (Table 2S, Supporting Information) previously determined in these animals [23] as well as Cd concentration in the bone tissue (Table 35, Supporting Information) [22] were evaluated.

\section{Results}

$\nabla$

The administration of AME alone for 3, 10, and 17 months increased the TAS of the serum and had no influence on its TOS or OSI, except for a decrease in OSI after 10 months. After 24 months, TAS and TOS were lower, but the OSI was unchanged, compared to the control group ( $\bullet$ Fig. 1 ). In the animals treated with the $1 \mathrm{mg} \mathrm{Cd} / \mathrm{kg}$ diet, TAS decreased from the 17th month, whereas at the higher exposure, it decreased from the 10th month ( Fig. 1). TOS and OSI were dose- and exposure duration-dependently increased compared to the control group ( Fig. 1). The level of oxidative stress in the serum (expressed as OSI) at both levels of Cd treatment gradually increased throughout the whole experiment. The Cd-induced disturbances of the oxidative/antioxidative balance in the serum after 3,10 , and 17 months were more advanced at the higher exposure, but after 24 months, they were similar at the 1 and $5 \mathrm{mg} \mathrm{Cd} / \mathrm{kg}$ diets ( Fig. 1). The administration of AME at both levels of Cd exposure markedly (partially or completely) improved the antioxidative status of the serum ( $\bullet$ Fig. 1). The serum TAS was higher in all groups receiving AME under Cd exposure, whereas TOS and OSI were lower compared to the respective groups treated with $\mathrm{Cd}$ alone, except for a lack of difference in TOS between the $\mathrm{Cd}_{1}$ and $\mathrm{Cd}_{1}+\mathrm{AME}$ groups after 3 months. However, the fact that the serum TOS in the last group at this time point did not differ compared to the control group indicates a beneficial impact of AME (॰ Fig. 1).

The administration of AME alone for up to 24 months had no impact on TAS or any of the determined indices of the enzymatic (GPx, GR, SOD, and CAT) and nonenzymatic (GSH, T-SH) status of the bone tissue, except for an increase in the activities of GPX after 3 months and SOD after 17 months ( Figs. 2-4, Table 1). The exposure to the 1 and $5 \mathrm{mg} \mathrm{Cd} / \mathrm{kg}$ diets for 3 and 10 months decreased the bone tissue TAS; however, this effect was not observed after the longer exposure ( $\bullet$ Fig. 2 ). As is evident from the data presented in $\odot$ Figs. 3 and 4, the bone activities of GPx, SOD, and CAT were unchanged or decreased, depending on the exposure duration. The activity of GR was unchanged after 3, 10, and 17 months, except for an increase in GR activity in the $\mathrm{Cd}_{5}$ group after 3 months, but increased after 24 months. The bone concentration of GSH was unchanged due to the exposure to $\mathrm{Cd}$, except for its decrease (by about $45 \%$ ) in the $\mathrm{Cd}_{1}$ and $\mathrm{Cd}_{5}$ groups after 10 months ( Table 1 ). The exposure to the 1 and $5 \mathrm{mg} \mathrm{Cd} /$ $\mathrm{kg}$ diets also resulted in a decrease in the concentration of T-SH in the bone tissue after 3 (by $47 \%$ and $62 \%$, respectively) and 24 months (by $39 \%$ and $46 \%$, respectively). The Cd-induced changes in the antioxidative status of the bone tissue were similar at both levels of exposure; however, at some time points, the activities of SOD and CAT were lower, whereas the activities of GPX and GR were higher in the $\mathrm{Cd}_{5}$ group than in the $\mathrm{Cd}_{1}$ group ( Figs. 2-4, Table 1). Consumption of AME under exposure to Cd not only completely prevented this metal-induced decrease in the bone tissue TAS, but even enhanced the value of this parameter $\left(\mathrm{Cd}_{1}+\right.$ AME group after 3 and 10 months, and $\mathrm{Cd}_{5}+$ AME group after 10 months) compared to the control group ( $\bullet$ Fig. 2). AME administration under exposure to $\mathrm{Cd}$ improved the enzymatic and nonenzymatic antioxidative barrier. In most cases, it completely prevented the Cd-induced decrease in GPX, SOD, and CAT, except for GPx activity after 24 months and CAT activity after 10 months in the $\mathrm{Cd}_{1}+\mathrm{AME}$ group. Moreover, AME coadministration under the whole treatment with the $5 \mathrm{mg} \mathrm{Cd} / \mathrm{kg}$ diet decreased GR activity, and after 24 months, this effect was also observed at the lower 

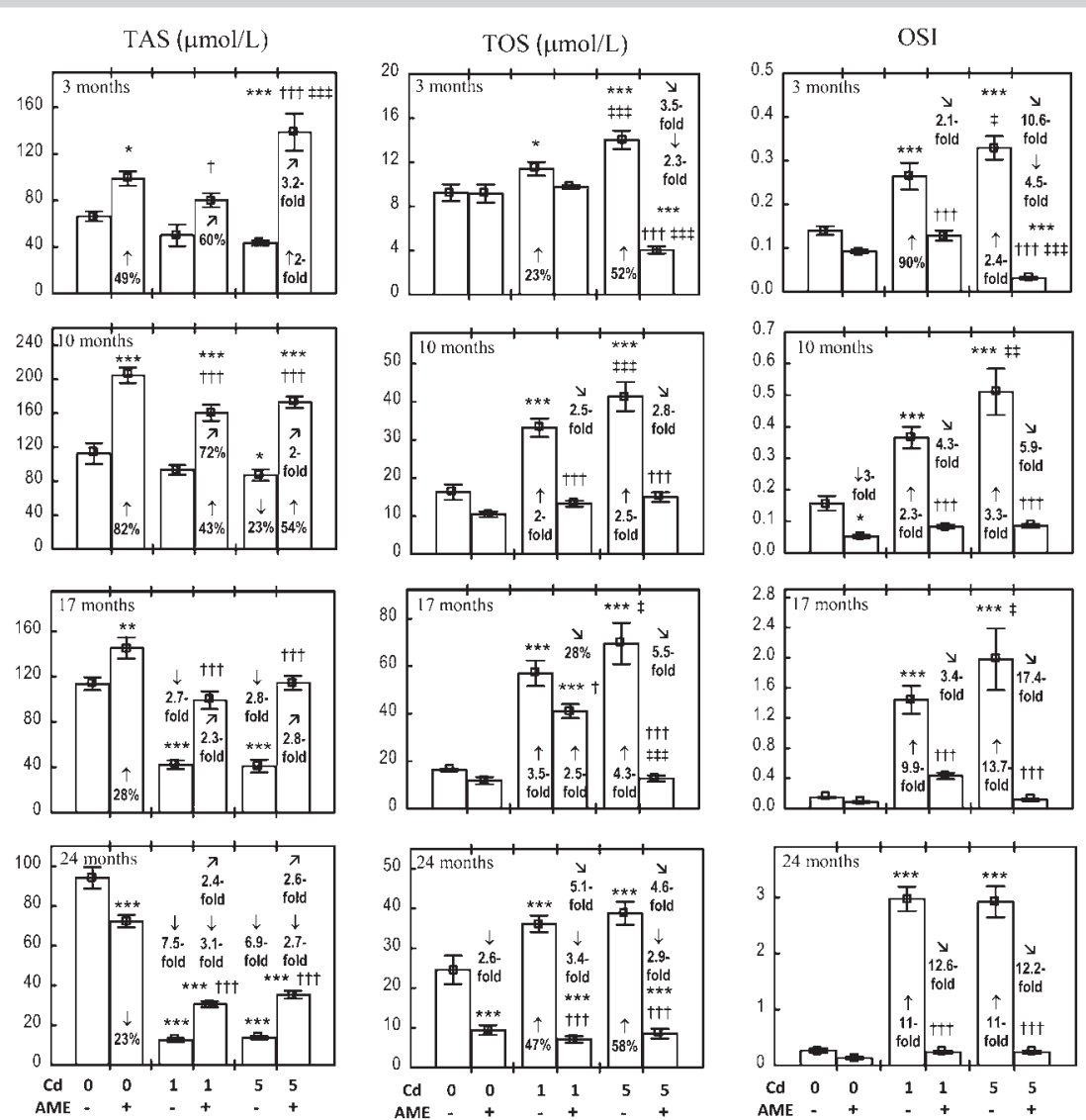

Fig. 1 Effect of AME on the oxidative/antioxidative balance in the serum of rats chronically exposed to $\mathrm{Cd}$. The rats received $\mathrm{Cd}$ in their diet at concentrations of 0,1 , and $5 \mathrm{mg} / \mathrm{kg}$ and $0.1 \%$ aqueous AME or not ("+" and "-", respectively). Data are represented as mean \pm SE for 8 rats, except for 7 animals in the AME group, and the groups exposed to the 1 and $5 \mathrm{mg} \mathrm{Cd} / \mathrm{kg}$ diets alone after 24 months. Statistically significant differences (Anova, Duncan's multiple range test): ${ }^{*} p<0.05,{ }^{* * *} p<0.001$ vs. control group; ${ }^{\dagger} p<0.05,{ }^{1 \dagger} p<0.001$ vs. respective group receiving $\mathrm{Cd}$ alone; ${ }^{\dagger} \mathrm{p}<0.05, \# \mathrm{p}<0.001$ vs. respective group receiving $1 \mathrm{mg} \mathrm{Cd} / \mathrm{kg}$ diet (alone or with AME). Numerical values in bars or above the bars indicate the percentage change or a factor of change compared to the control group ( $\downarrow$ decrease; $\uparrow$ increase) or the respective group receiving $C d$ alone ( $\supset$ decrease; $>$ increase).
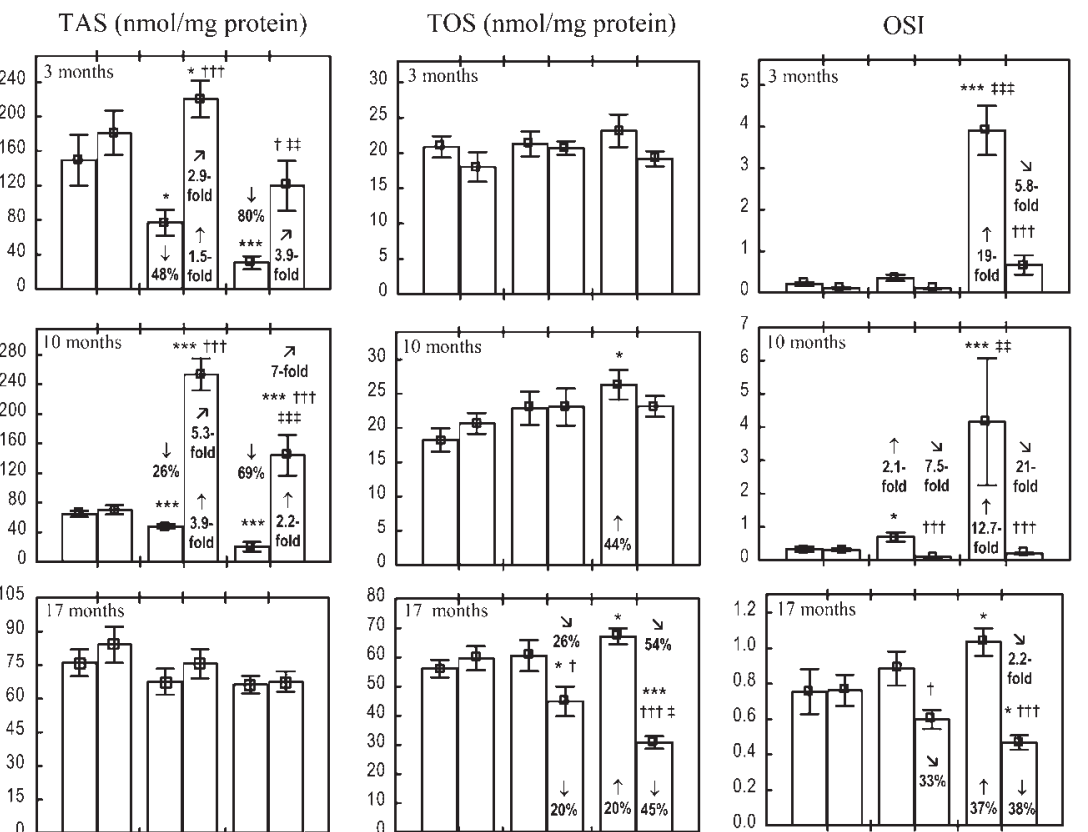

Fig. 2 Effect of AME on TAS and TOS status and OSI in the bone tissue of rats chronically exposed to $\mathrm{Cd}$. The rats received $\mathrm{Cd}$ in their diet at concentrations of 0,1 , and $5 \mathrm{mg} / \mathrm{kg}$ and $0.1 \%$ aqueous AME or not ("+" and "-", respectively). Data are represented as mean \pm SE for 8 rats, except for 7 animals in the AME group, and the groups exposed to the 1 and $5 \mathrm{mg} \mathrm{Cd} / \mathrm{kg}$ diets alone after 24 months. Statistically significant differences (Anova, Duncan's multiple range test): ${ }^{*} p<0.05,{ }^{* *} p<0.01$, ${ }^{* * *} p<0.001$ vs. control group; ${ }^{\dagger} p<0.05$, $\pi i \mathrm{p}<0.001$ vs. respective group receiving $\mathrm{Cd}$ alone; ${ }^{ \pm} p<0.05, \# p<0.01, \# p<0.001$ vs. respective group receiving $1 \mathrm{mg} \mathrm{Cd} / \mathrm{kg}$ diet (alone or with AME). Numerical values in bars or above the bars indicate the percentage change or a factor of change compared to the control group ( $\downarrow$ decrease; $\uparrow$ increase) or the respective group receiv-
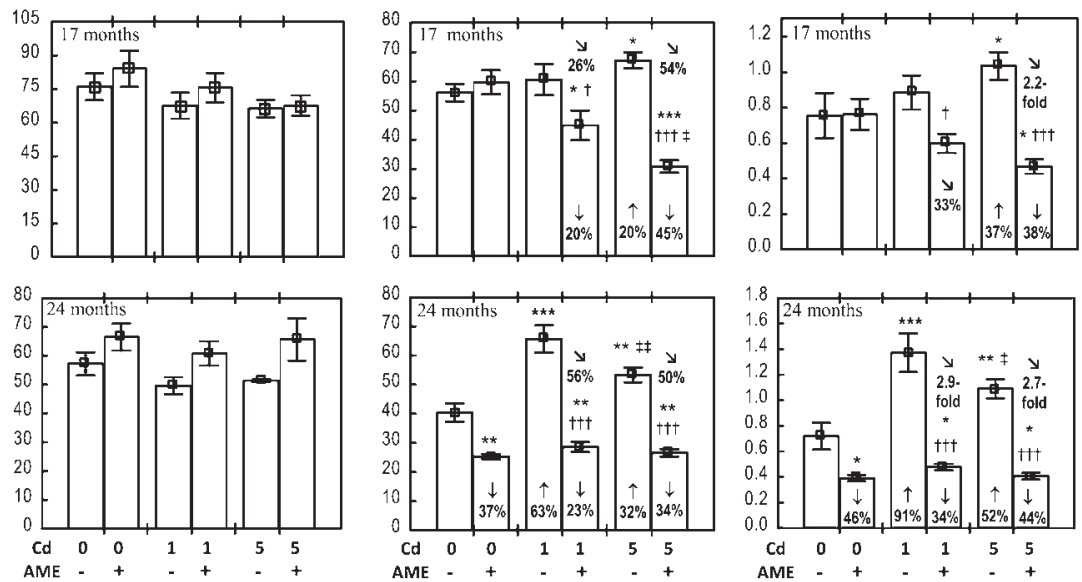

ing $C d$ alone ( $\supset$ decrease; $\nearrow$ increase). 
Table 1 Effect of AME on GSH and T-SH concentration in the bone tissue at the distal femoral epiphysis of rats exposed to $\mathrm{Cd}$.

\begin{tabular}{|c|c|c|c|c|}
\hline \multirow[t]{2}{*}{ Group } & \multicolumn{4}{|c|}{ Experiment duration } \\
\hline & 3 months & 10 months & 17 months & 24 months \\
\hline \multicolumn{5}{|c|}{ GSH (nmol/mg protein) } \\
\hline Control & $1.628 \pm 0.130$ & $2.308 \pm 0.429$ & $2.507 \pm 0.331$ & $2.437 \pm 0.224$ \\
\hline AME & $2.163 \pm 0.377$ & $1.564 \pm 0.236$ & $1.945 \pm 0.238$ & $2.241 \pm 0.298$ \\
\hline $\mathrm{Cd}_{1}$ & $1.426 \pm 0.163$ & $1.258 \pm 0.073^{*}$ & $2.480 \pm 0.327$ & $2.680 \pm 0.199$ \\
\hline $\mathrm{Cd}_{1}+\mathrm{AME}$ & $1.386 \pm 0.214$ & $1.902 \pm 0.246$ & $2.702 \pm 0.390$ & $2.314 \pm 0.177$ \\
\hline $\mathrm{Cd}_{5}$ & $1.862 \pm 0.270$ & $1.300 \pm 0.226^{*}$ & $2.972 \pm 0.309$ & $2.477 \pm 0.269$ \\
\hline $\mathrm{Cd}_{5}+\mathrm{AME}$ & $1.438 \pm 0.244$ & $1.562 \pm 0.216$ & $2.189 \pm 0.240$ & $2.301 \pm 0.203$ \\
\hline \multicolumn{5}{|c|}{ T-SH (nmol/mg protein) } \\
\hline Control & $48.12 \pm 6.89$ & $44.39 \pm 5.45$ & $70.65 \pm 6.29$ & $64.97 \pm 12.17$ \\
\hline AME & $44.83 \pm 3.27$ & $37.94 \pm 3.57$ & $69.74 \pm 6.56$ & $73.95 \pm 8.50$ \\
\hline $\mathrm{Cd}_{1}$ & $25.26 \pm 3.54^{* * *}$ & $30.76 \pm 3.39$ & $69.03 \pm 6.06$ & $39.80 \pm 4.04^{*}$ \\
\hline $\mathrm{Cd}_{1}+\mathrm{AME}$ & $31.15 \pm 2.46^{* *}$ & $37.02 \pm 5.06$ & $59.26 \pm 11.43$ & $52.57 \pm 4.98$ \\
\hline $\mathrm{Cd}_{5}$ & $18.07 \pm 1.53^{* * *}$ & $29.25 \pm 2.78$ & $61.54 \pm 5.24$ & $34.77 \pm 2.27^{*}$ \\
\hline $\mathrm{Cd}_{5}+\mathrm{AME}$ & $26.17 \pm 2.81^{* * *}$ & $40.47 \pm 7.61$ & $52.36 \pm 6.27$ & $63.11 \pm 5.62^{\dagger}$ \\
\hline
\end{tabular}

Data are represented as mean \pm SE for 8 rats, except for 7 animals in the AME, $\mathrm{Cd}_{1}$, and $\mathrm{Cd}_{5}$ groups after 24 months. Statistically significant differences (Anova, Duncan's multiple range test) compared to the control group ( ${ }^{*} \mathrm{p}<0.05,{ }^{* *} \mathrm{p}<0.01$,

$\left.{ }^{* * *} \mathrm{p}<0.001\right)$ and respective group receiving $C d$ alone $\left({ }^{\dagger} \mathrm{p}<0.05\right)$ are marked

exposure ( $\bullet$ Fig. 3). The consumption of AME provided complete protection from the 10-month exposure to the 1 and $5 \mathrm{mg} \mathrm{Cd} / \mathrm{kg}$ diets that caused a decrease in the bone tissue GSH concentration and from the decrease in the concentration of T-SH after 24 months, but not after 3 months ( Table 1). Numerous correlations between the assayed indices of antioxidative bone status were noted (Table 4S, Supporting Information).

The administration of AME alone for 24 months, but not for shorter periods, decreased the TOS of the bone tissue and the level of oxidative stress expressed as OSI ( Fig. 2). Moreover, the consumption of AME alone throughout the experiment had no impact on the $\mathrm{H}_{2} \mathrm{O}_{2}$ concentration in the bone tissue ( Fig.4). In the rats exposed to the $5 \mathrm{mg} \mathrm{Cd} / \mathrm{kg}$ diet, the TOS of the bone tissue was increased from the 10th month of the experiment, whereas at the lower treatment, this effect was observed only after 24 months ( Fig. 2). Treatment with the $5 \mathrm{mg} \mathrm{Cd} / \mathrm{kg}$ diet induced oxidative stress (expressed as OSI) in the bone tissue already after 3 months and the effect was more markedly advanced after 3 and 10 months than after 17 and 24 months. In the animals intoxicated with the $1 \mathrm{mg} \mathrm{Cd} / \mathrm{kg}$ diet, the OSI was increased after 10 and 24 months. At both levels of $\mathrm{Cd}$ exposure, the concentration of $\mathrm{H}_{2} \mathrm{O}_{2}$ in the bone tissue was increased after 10 and 24 months ( Fig. 4). The administration of AME under the exposure to the 1 and $5 \mathrm{mg} \mathrm{Cd} / \mathrm{kg}$ diets completely prevented this heavy metal-induced increase in the bone concentration of $\mathrm{H}_{2} \mathrm{O}_{2}$ (๑ Fig. 4), TOS, and OSI ( Fig. 2). After 17 and 24 months, TOS and OSI in the $\mathrm{Cd}_{1}+\mathrm{AME}$ and $\mathrm{Cd}_{5}+$ AME groups, except for OSI in the $\mathrm{Cd}_{1}+\mathrm{AME}$ group after 17 months, were even lower than the respective control values ( $\bullet$ Fig. 2 ).

The administration of AME alone for 3, 17, and 24 months decreased the bone concentration of PC ( Fig. 5). After 24 months, the bone concentrations of 8-isoP, LPO, and 8-OHdG also decreased ( Figs. 5 and 6). The exposure to 1 and $5 \mathrm{mg} \mathrm{Cd} / \mathrm{kg}$ diets for 10,17 , and 24 months increased the bone tissue concentration of PC, whereas concomitant AME administration provided partial (after 10 and 17 months) or complete (after 24 months) protection from this change. Moreover, PC concentration in the $\mathrm{Cd}_{1}+\mathrm{AME}$ and $\mathrm{Cd}_{5}+\mathrm{AME}$ groups after 3 months was lower com-
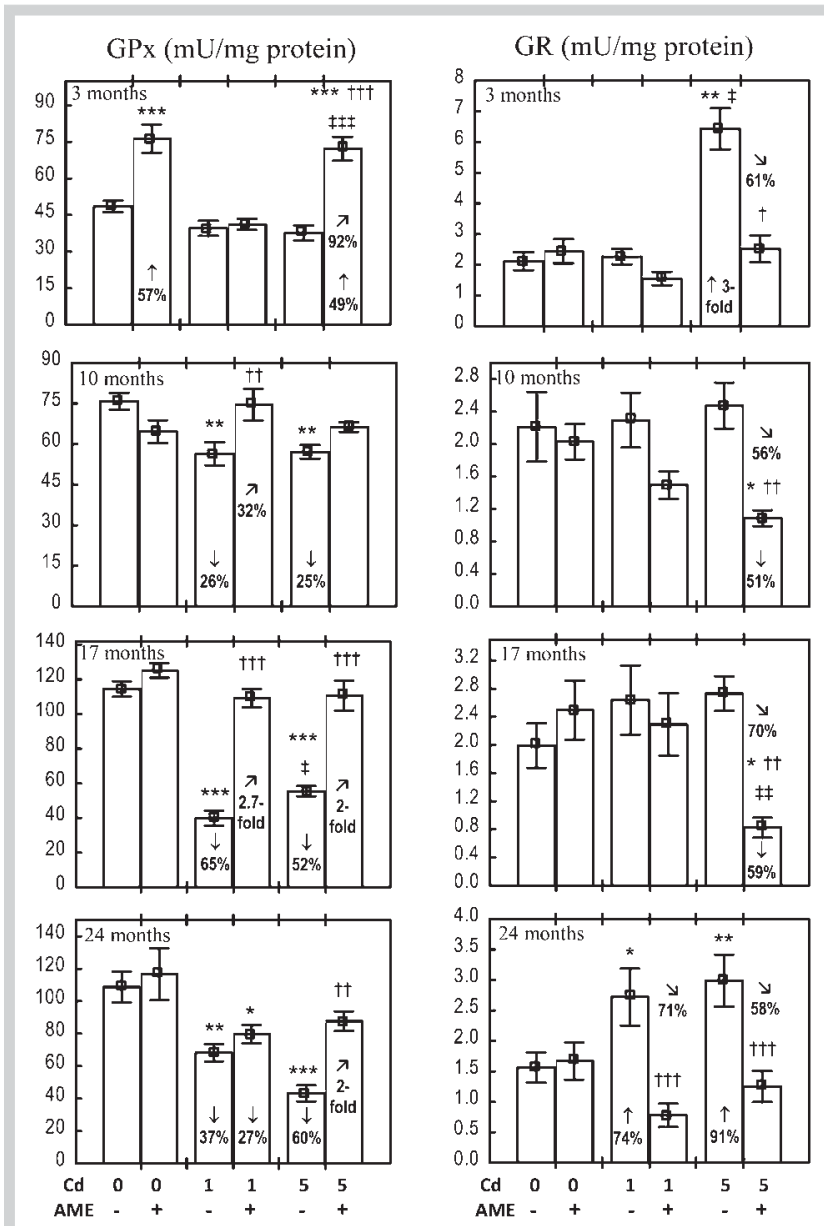

Fig. 3 Effect of AME on the activities of GPx and GR in the bone tissue of rats chronically exposed to $\mathrm{Cd}$. The rats received $\mathrm{Cd}$ in their diet at concentrations of 0,1 , and $5 \mathrm{mg} / \mathrm{kg}$ and $0.1 \%$ aqueous AME or not ("+" and “-", respectively). Data are represented as mean \pm SE for 8 rats, except for 7 animals in the AME group, and the groups exposed to the 1 and $5 \mathrm{mg} \mathrm{Cd} /$ $\mathrm{kg}$ diets alone after 24 months. Statistically significant differences (Anova, Duncan's multiple range test): ${ }^{*} p<0.05,{ }^{* *} p<0.01,{ }^{* * *} p<0.001$ vs. control group; ${ }^{\dagger} p<0.05, " 1 \mathrm{p}<0.01, " \pi \mathrm{p}<0.001 \mathrm{vs}$. respective group receiving Cd alone; ${ }^{\ddagger} p<0.05, \# p<0.01, \# p<0.001$ vs. respective group receiving $1 \mathrm{mg} \mathrm{Cd} / \mathrm{kg}$ diet (alone or with AME). Numerical values in bars or above the bars indicate the percentage change or a factor of change compared to the control group ( $\downarrow$ decrease; $\uparrow$ increase) or the respective group receiving $C d$ alone ( $\$ decrease; $\gg$ increase).

pared to the $\mathrm{Cd}_{1}$ and $\mathrm{Cd}_{5}$ groups, respectively ( $\bullet$ Fig. 5 ). The bone concentration of 8-isoP in the animals exposed to the 1 and $5 \mathrm{mg}$ $\mathrm{Cd} / \mathrm{kg}$ diets alone was increased throughout the experiment, except for the $\mathrm{Cd}_{5}$ group after 3 months. The concomitant administration of AME completely prevented this impact of Cd. Moreover, the bone 8 -isoP concentration in the $\mathrm{Cd}_{1}+\mathrm{AME}$ group after 17 months, and in the $\mathrm{Cd}_{5}+\mathrm{AME}$ group after 24 months, was even lower compared to the control group ( Fig. 6). The exposure to Cd alone had no impact on the bone concentration of LPO, except for its increase in the $\mathrm{Cd}_{5}$ group after 24 months ( $\bullet$ Fig. 6 ). The bone tissue concentration of LPO in the $\mathrm{Cd}_{1}+\mathrm{AME}$ group after 3 and 24 months, and in the $\mathrm{Cd}_{5}+$ AME group after 17 and 24 months, was lower than in the control group, providing clear evidence of the protective impact of AME ( Fig. 6). The exposure to the $1 \mathrm{mg} \mathrm{Cd} / \mathrm{kg}$ diet for up to 24 months had no impact on the bone tissue concentration of $8-\mathrm{OHdG}$, whereas at the higher 


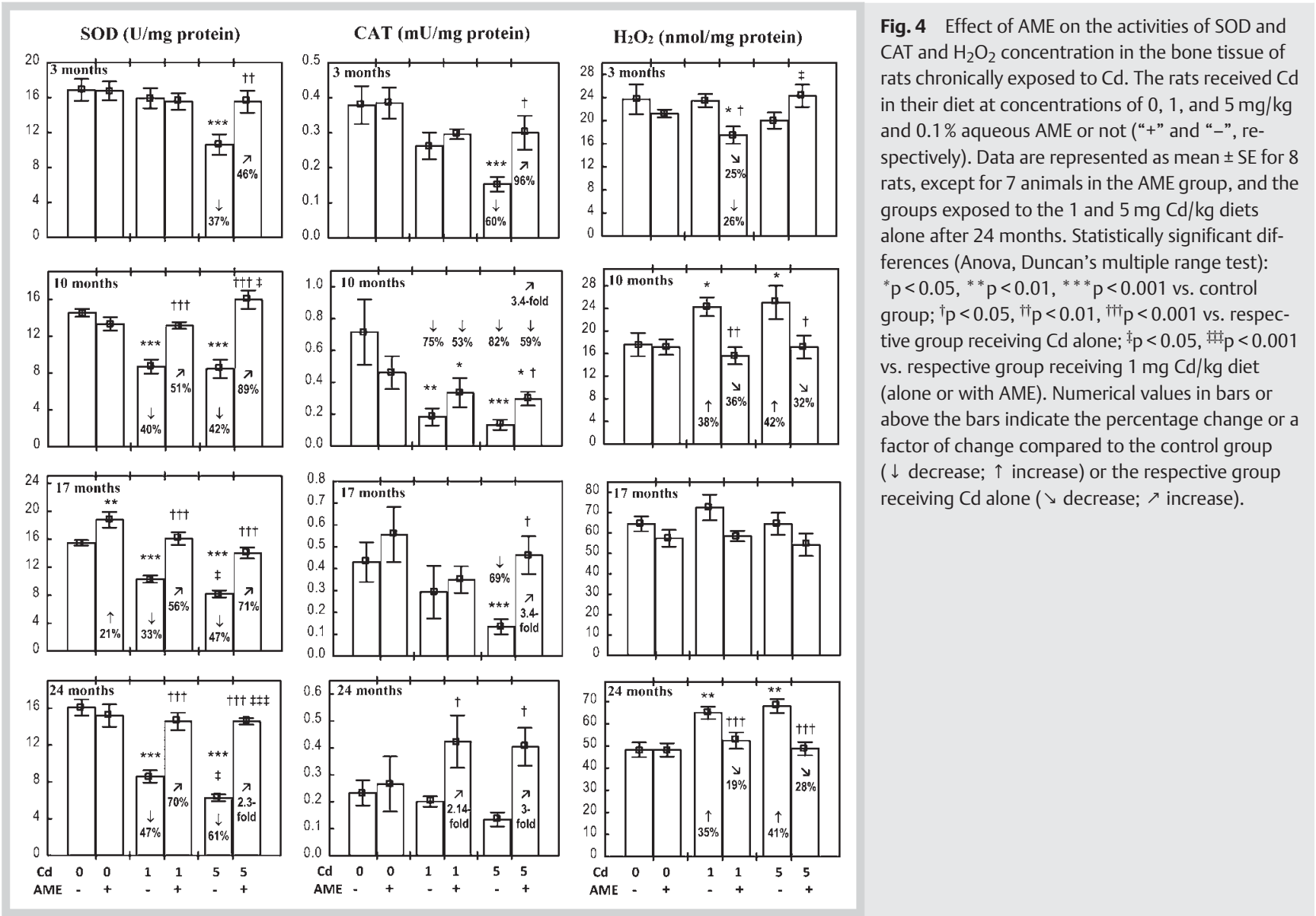

treatment, the value of this marker of oxidative DNA damage was increased after 17 and 24 months ( Fig. 5). AME not only provided complete protection from the Cd-induced increase in 8OHdG, but also after 24 months at both levels of this metal treatment, the value of this parameter was even lower compared to the control group. Moreover, the beneficial effect of AME consumption, under intoxication with the 1 and $5 \mathrm{mg} \mathrm{Cd} / \mathrm{kg}$ diets in terms oxidative DNA damage, was evident already after 10 months, as the concentration of 8-OHdG in the $\mathrm{Cd}_{1}+\mathrm{AME}$ and $\mathrm{Cd}_{5}+$ AME groups was lower compared to the respective groups treated with Cd alone ( $\bullet$ Fig. 5 ).

The results of the ANOVA/MANOVA analysis suggest that the improvement of the oxidative/antioxidative status of the serum and bone, and protection from oxidative changes in the bone tissue due to AME administration under the exposure to $\mathrm{Cd}$, was the result of both an independent action of the extract and an interaction of its ingredients with $\mathrm{Cd}$; however, the independent effect of AME seems to be stronger (Tables 5S-7S, Supporting Information).

Numerous positive dependences occurred between indices of oxidative bone status and markers of oxidative protein, lipid, and DNA damage in the bone tissue of rats receiving AME (alone and with $\mathrm{Cd}$; Table 8S, Supporting Information). Moreover, a close relationship existed between the oxidative/antioxidative status of the serum and bone (Table 95, Supporting Information). In the rats administered AME, alone and under Cd exposure, numerous correlations were noted between indices of the oxidative/antioxidative bone status and markers of bone turnover in the serum (concentrations of OC and CTX) and bone tissue (activity of ALP, concentrations of SRANKL and OPG and the ratio of
sRANKL/OPG; $\odot$ Table 2) as well as the femur BMD and indices of bone mineral status at the femoral distal epiphysis (\% mineral comp., $\mathrm{Ca} / \mathrm{AW}$, and $\mathrm{Ca} / \mathrm{DW}$; $\odot$ Table 3 ) previously determined in these animals [23]. TAS and some other indices of the antioxidative bone status positively correlated with the markers of bone formation and indices of the bone mineral status, and negatively with chosen markers of bone resorption. Moreover, TOS, OSI, and numerous other indices of oxidative bone status, including markers of oxidative modifications of lipid, protein, and DNA, negatively correlated with the indices of bone formation, and positively with bone resorption markers ( Tables 2 and 3).

In the animals receiving or not receiving AME under the exposure to $\mathrm{Cd}$, negative correlations were noted between this heavy metal concentration in the bone at the distal femoral epiphysis and TAS $(r=-0.232, p<0.01)$, the activities of GPX, SOD, and CAT $(r=-0.303, r=-0.485, r=-0.268$, respectively; $\mathrm{p}<0.001)$, as well as the T-SH concentration $(r=-0.231, p<0.01)$. Moreover, the bone $\mathrm{Cd}$ concentration positively correlated $(\mathrm{p}<0.001)$ with OSI $(r=0.262)$ and the concentrations of PC $(r=0.248)$ and 8 -isoP $(\mathrm{r}=0.297)$.

\section{Discussion}

$\nabla$

The present paper has been focused on the involvement of the oxidative defense system in the mechanisms of the osteoprotective impact of a polyphenol-rich chokeberry extract under exposure to $\mathrm{Cd}$. Oxidative-reductive processes are an integral component of continuously ongoing bone remodelling, and the bone tis- 
$\mathrm{PC}$ (nmol/mg protein)
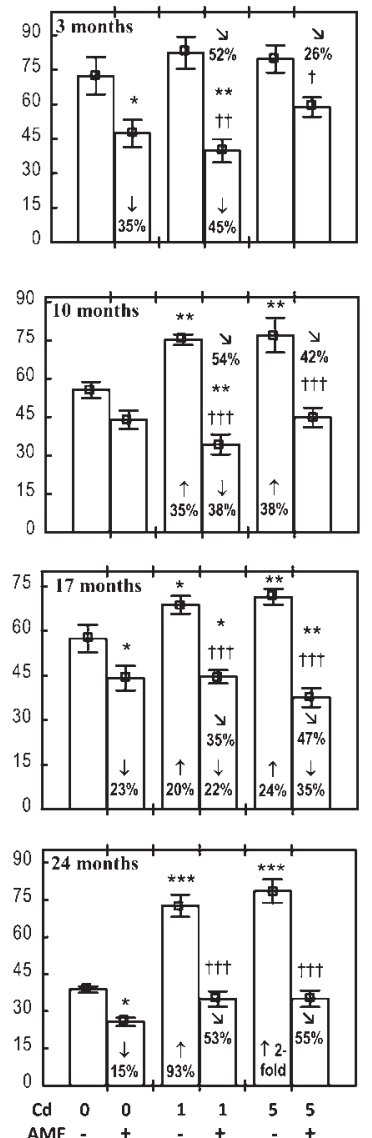

8-OHdG (ng/mg protein)
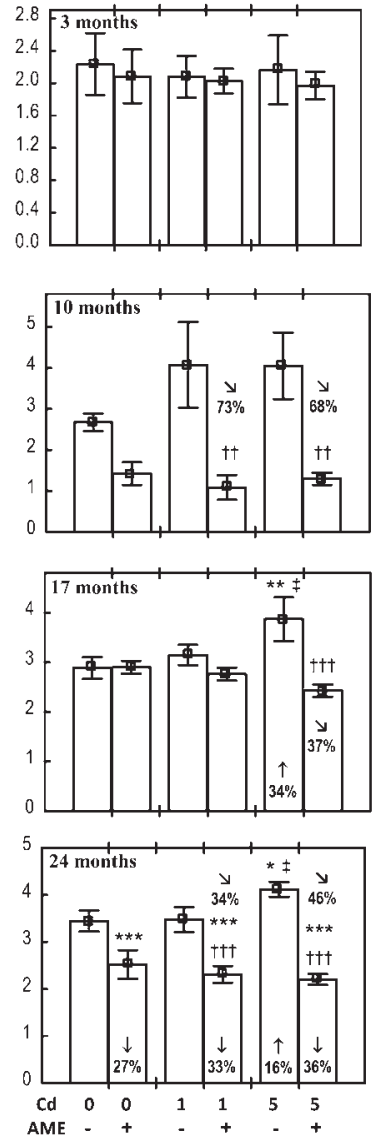

Fig. 5 Effect of AME on oxidative protein and DNA damage in the bone tissue of rats chronically exposed to $\mathrm{Cd}$. The rats received $\mathrm{Cd}$ in their diet at concentrations of 0,1 , and $5 \mathrm{mg} / \mathrm{kg}$ and $0.1 \%$ aqueous AME or not ("+" and “-", respectively). Data are represented as mean \pm SE for 8 rats, except for 7 animals in the AME group, and the groups exposed to the 1 and $5 \mathrm{mg}$ $\mathrm{Cd} / \mathrm{kg}$ diets alone after 24 months. Statistically significant differences (Anova, Duncan's multiple range test): ${ }^{*} \mathrm{p}<0.05,{ }^{*} \mathrm{p}<<0.01,{ }^{* * *} \mathrm{p}<0.001$ vs. control group; ${ }^{\dagger} p<0.05, \pi p<0.01,{ }^{\dagger \dagger} p<0.001$ vs. respective group receiving $\mathrm{Cd}$ alone; ${ }^{\mathrm{t}} \mathrm{p}<0.05$ vs. respective group receiving $1 \mathrm{mg} \mathrm{Cd} / \mathrm{kg}$ diet (alone or with AME). Numerical values in bars or above the bars indicate the percentage change or a factor of change compared to the control group ( $\downarrow$ decrease; $\uparrow$ increase) or the respective group receiving $C d$ alone ( $\downarrow$ decrease).

sue oxidative/antioxidative status plays an important role in its physiology and pathology [24-27]. Oxidative stress has been recognized as one of the mechanisms of osteotoxic Cd action [24,26, 27]; however, the exact mechanisms of this metal's involvement in the development of bone damage have not been explained until now. Based on the available data [24,26,27], it seems that Cdinduced ROS, which cannot be removed due to their excessive generation, and insufficient antioxidative protection may cause oxidative damage to the macromolecules in the bone tissue and influence the bone turnover. Excessive production and accumulation of ROS has a detrimental impact on bone metabolism via influencing the RANK/RANKL/OPG system [24-26]. ROS (particularly $\mathrm{H}_{2} \mathrm{O}_{2}$ ) increases the number of osteoclasts and activates their function, leading to a loss of bone mass and a decrease in bone formation via inhibiting osteoblasts generation from osteo-
LPO (nmol/mg protein)
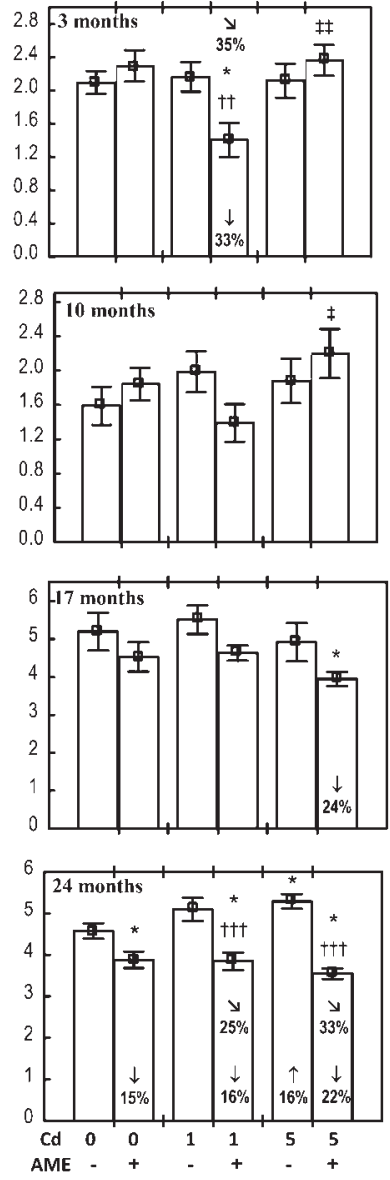

8-isoP (pg/mg protein)
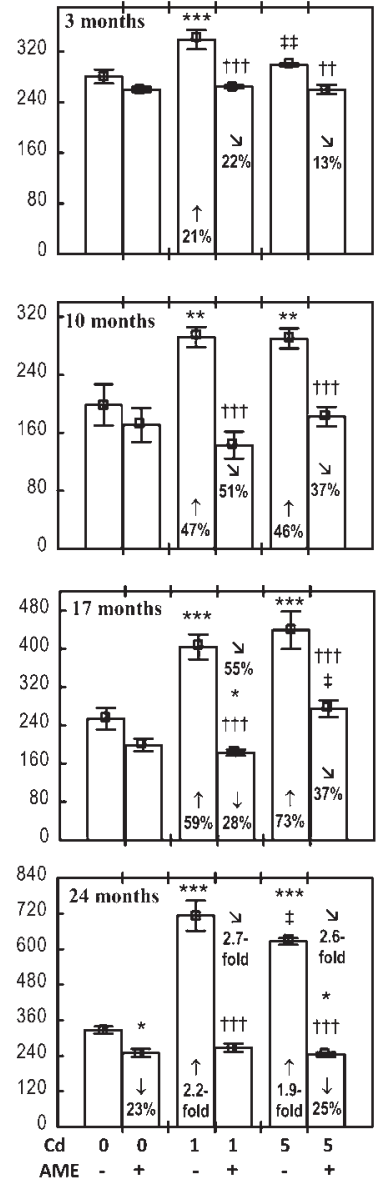

Fig. 6 Effect of AME on lipid peroxidation in the bone tissue of rats chronically exposed to $\mathrm{Cd}$. The rats received $\mathrm{Cd}$ in their diet at concentrations of 0,1 , and $5 \mathrm{mg} / \mathrm{kg}$ and $0.1 \%$ aqueous AME or not ("+" and “-”, respectively). Data are represented as mean \pm SE for 8 rats, except for 7 animals in the AME group, and the groups exposed to the 1 and $5 \mathrm{mg} \mathrm{Cd} / \mathrm{kg}$ diets alone after 24 months. Statistically significant differences (Anova, Duncan's multiple range test): ${ }^{*} p<0.05,{ }^{* *} p<0.01,{ }^{* * *} p<0.001$ vs. control group; ${ }^{\dagger} p<0.05,{ }^{\top} p<0.01,{ }^{\dagger \dagger} p<0.001$ vs. respective group receiving Cd alone; ${ }^{\ddagger} \mathrm{p}<0.05,{ }_{\mathrm{H}} \mathrm{p}<0.01 \mathrm{vs}$. respective group receiving $1 \mathrm{mg} \mathrm{Cd} / \mathrm{kg}$ diet (alone or with AME). Numerical values in bars or above the bars indicate the percentage change or a factor of change compared to the control group ( $\downarrow$ decrease; $\uparrow$ increase) or the respective group receiving $C d$ alone ( $\searrow$ decrease).

progenitor cells and shortening their survival [25]. The possible mechanisms of pro-oxidative $\mathrm{Cd}$ action in the bone tissue and oxidative stress involvement in the development of damage to the skeleton have been previously reported by us [24,27] and thus they are not discussed in detail in this paper.

The measurements performed in the present study not only confirmed our previous findings, but they also revealed that this heavy metal deregulates the oxidative-reductive processes, leading to the development of oxidative stress with oxidative lipid and protein modifications in the bone tissue, even at lower exposure ( $1 \mathrm{mg} \mathrm{Cd} / \mathrm{kg}$ diet) and lower bone concentration (0.0425 \pm $0.0036 \mu \mathrm{g} / \mathrm{g}$ dry wt.) than had previously been revealed $[24,27]$. The fact that TAS was unchanged due to the 24-month exposure to the 1 and $5 \mathrm{mg} \mathrm{Cd} / \mathrm{kg}$ diets in spite of the decreased activities of GPX and SOD may be explained by the increased GR activity, 
Table 2 Relationships between markers of bone turnover and indices of the oxidative/antioxidative status of the bone tissue in rats receiving AME alone and under exposure to $\mathrm{Cd}$

\begin{tabular}{|c|c|c|c|c|c|c|}
\hline & \multicolumn{2}{|l|}{ Serum } & \multicolumn{3}{|c|}{ Bone tissue at the distal femoral diaphysis } & \multirow[b]{2}{*}{ SRANKL/OPG } \\
\hline & OC & CTX & ALP & OPG & sRANKL & \\
\hline \multicolumn{7}{|c|}{ Indices of antioxidative status } \\
\hline TAS & $0.311^{* * *}$ & NS & $0.318^{* * *}$ & NS & NS & $-0.206^{* *}$ \\
\hline GPx & $0.430^{* * *}$ & $-0.399 * * *$ & $-0.211^{* *}$ & $0.524^{* * *}$ & $-0.230^{* * *}$ & $-0.522^{* * *}$ \\
\hline GR & $-0.252^{* * *}$ & $0.323^{* * *}$ & NS & $-0.263^{* * *}$ & $0.328^{* * *}$ & $0.351^{* * *}$ \\
\hline SOD & $0.504^{* * *}$ & NS & $0.378^{* * *}$ & $0.436 * * *$ & $-0.270 * * *$ & $-0.507^{* * *}$ \\
\hline CAT & $0.265^{* * *}$ & $-0.164^{*}$ & $0.228 * *$ & $0.301^{* * *}$ & $-0.301^{* * *}$ & $-0.421^{* * *}$ \\
\hline GSH & $0.166^{*}$ & NS & $-0.394^{* * *}$ & $0.223^{* *}$ & $0.208^{* *}$ & NS \\
\hline T-SH & $0.261^{* * *}$ & NS & $-0.334^{* * *}$ & $0.356^{* * *}$ & NS & $-0.266^{* * *}$ \\
\hline \multicolumn{7}{|c|}{ Indices of oxidative status } \\
\hline TOS & NS & $0.143^{*}$ & $-0.634^{* * *}$ & NS & $0.491^{* * *}$ & $0.207^{* *}$ \\
\hline OSI & $-0.171^{*}$ & $0.235^{* *}$ & $-0.437^{* * *}$ & NS & $0.496^{* * *}$ & $0.390^{* * *}$ \\
\hline $\mathrm{H}_{2} \mathrm{O}_{2}$ & NS & $0.173^{*}$ & $-0.673^{* * *}$ & $0.205^{* *}$ & $0.440^{* * *}$ & NS \\
\hline PC & $-0.370^{* * *}$ & $0.423^{* * *}$ & NS & $-0.369^{* * *}$ & $0.377^{* * *}$ & $0.495^{* * *}$ \\
\hline 8-isoP & $-0.375^{* * *}$ & $0.397^{* * *}$ & $-0.349^{* * *}$ & $-0.372^{* * *}$ & $0.509^{* * *}$ & $0.581^{* * *}$ \\
\hline LPO & NS & $0.169^{*}$ & $-0.654^{* * *}$ & $0.213^{* * *}$ & $0.436^{* * *}$ & NS \\
\hline $8-\mathrm{OHdG}$ & $-0.175^{*}$ & $0.152^{*}$ & $-0.485^{* * *}$ & NS & $0.338^{* * *}$ & $0.193^{* *}$ \\
\hline
\end{tabular}

Data are represented as a correlation coefficient $(r)$ and the level of statistical significance $(p) ;{ }^{*} p<0.05,{ }^{* *} p<0.01,{ }^{* * *} p<0.001 ;$ NS: not statistically significant $(p>0.05)$

which might be a defensive response to the decreased GPx activity. The increased bone concentration of $\mathrm{H}_{2} \mathrm{O}_{2}$ might result from both its insufficient detoxification due to the decreased activity of GPX and/or CAT, and increased production. It seems possible that $\mathrm{Cd}$ might stimulate ROS formation, including $\mathrm{H}_{2} \mathrm{O}_{2}$, and affect their detoxification via influencing (directly and indirectly) the activity of the bone cells $[24,26]$.

The present paper is the first report providing evidence that the consumption of chokeberry extract under chronic exposure to $\mathrm{Cd}$ may offer protection from oxidative stress and oxidative modifications of protein, lipid, and DNA in the bone tissue, and that its protective action against $\mathrm{Cd}$-induced bone damage is mediated by the oxidative defense system. The protective effect of AME can be explained by its high content of polyphenolic compounds, especially including anthocyanins, which possess strong antioxidative potential $[13,14,18-20]$. Polyphenols act as direct free radical scavengers [20], inhibit the activities of pro-oxidative enzymes [20], and increase antioxidative enzyme activities [3,8,9] as well as play a role in the regeneration of antioxidative vitamins (vitamin C and E) $[29,30]$. The observations made in the animals receiving AME alone revealed the effectiveness of the extract in the improvement of the antioxidative system of the bone tissue. Moreover, other ingredients of $A$. melanocarpa berries, including vitamin C, vitamin E, $\beta$-carotene, and bioelements, which influence the activity of antioxidative enzymes such as manganese, zinc, copper, selenium, and iron [14], might also contribute to the favorable impact of AME. Owing to the relationship between the level of ROS and the rate of bone turnover [24-27], it should be taken into account that the direct beneficial impact of AME on the oxidative/antioxidative bone status under $\mathrm{Cd}$ exposure might also be related, at least partly, to the influence of some ingredients of the extract, including polyphenols and zinc, on the activity of osteoclasts and the process of bone formation $[27,31$, 32]. Chlorogenic acid has also been reported to inhibit osteoclasts differentiation and bone resorption by the downregulation of RANKL [31], whereas quercetin and zinc have been noted to stimulate bone formation [27,32-34]. Zinc not only stimulates osteoblasts proliferation and differentiation, but it also suppresses osteoclasts differentiation by, among others, antagonizing NF- $k$ B
Table 3 Relationships between indices of bone mineral status and oxidative/ antioxidative bone status in rats receiving AME alone and under exposure to Cd.

\begin{tabular}{|c|c|c|c|c|}
\hline & \multicolumn{4}{|c|}{ Indices of bone mineral status } \\
\hline & \multirow{2}{*}{$\begin{array}{l}\text { Femur } \\
\text { BMD }\end{array}$} & \multicolumn{3}{|c|}{ Bone tissue at the distal femoral epiphysis } \\
\hline & & $\begin{array}{l}\text { \% mineral } \\
\text { comp. }\end{array}$ & $\mathrm{Ca} / \mathrm{DW}$ & $\mathrm{Ca} / \mathrm{AW}$ \\
\hline \multicolumn{5}{|c|}{ Indices of antioxidative status } \\
\hline TAS & $0.302^{* * *}$ & $0.421^{* * *}$ & $0.331^{* * *}$ & NS \\
\hline GPx & $0.561^{* * *}$ & NS & $0.250^{* * *}$ & $0.331^{* * *}$ \\
\hline GR & $-0.297 * * *$ & NS & NS & NS \\
\hline SOD & $0.480 * * *$ & $0.503^{* * *}$ & $0.268 * * *$ & NS \\
\hline CAT & $0.270^{* * *}$ & $0.292^{* * *}$ & $0.275^{* * *}$ & $0.189^{*}$ \\
\hline GSH & $0.162^{*}$ & $-0.210^{* *}$ & NS & NS \\
\hline T-SH & $0.365^{* * *}$ & NS & NS & NS \\
\hline \multicolumn{5}{|c|}{ Indices of oxidative status } \\
\hline TOS & NS & $-0.524^{* * *}$ & $-0.144^{*}$ & NS \\
\hline OSI & $-0.276^{* * *}$ & $-0.541^{* * *}$ & $-0.260^{* * *}$ & NS \\
\hline $\mathrm{H}_{2} \mathrm{O}_{2}$ & NS & $-0.517^{* * *}$ & $-0.254^{* * *}$ & NS \\
\hline PC & $-0.612^{* * *}$ & $-0.184^{*}$ & $-0.149^{*}$ & $-0.201^{*}$ \\
\hline 8-isoP & $-0.430 * * *$ & $-0.271 * * *$ & $-0.536 * * *$ & $-0.506^{* * *}$ \\
\hline LPO & NS & $-0.455^{* * *}$ & $-0.259^{* * *}$ & NS \\
\hline 8-OHdG & $-0.198^{* *}$ & $-0.433^{* * *}$ & $-0.232^{* *}$ & NS \\
\hline
\end{tabular}

Data are represented as a correlation coefficient $(r)$ and the level of statistical significance $(\mathrm{p}) ;{ }^{*} \mathrm{p}<0.05,{ }^{* *} \mathrm{p}<0.01,{ }^{* * *} \mathrm{p}<0.001 ; \mathrm{NS}$ : not statistically significant $(\mathrm{p}>0.05)$

activation $[27,33,34]$. Polyphenols, due to their ability to bind $\mathrm{Cd}^{2+}[4]$, may decrease the body burden of $\mathrm{Cd}$ and thus protect against the effects of its direct and indirect action, resulting in the improvement of the oxidative/antioxidative balance and bone turnover $[6,15,22,23]$. It is also necessary to take into consideration that the molecular mechanisms of the beneficial impact of polyphenols on bone tissue metabolism might be related to the ability of these compounds to enhance the production of nitric oxide, which is essential for the induction of new bone formation [35], as well as to induce the nuclear factor erythroid 2related factor 2 (Nrf2)-mediated antioxidant gene expressions and thereby to decrease the oxidative status [7]. 
We have previously reported that AME administration under exposure to the $1 \mathrm{mg} \mathrm{Cd} / \mathrm{kg}$ diet had only a very slight protective impact against this metal's accumulation in the organism, whereas its application under treatment with the $5 \mathrm{mg} \mathrm{Cd} / \mathrm{kg}$ diet significantly decreased the apparent absorption and retention in the body and increased urinary concentration of this heavy metal, resulting in its lower concentration in the blood and lower accumulation in soft tissues (mainly in the liver and kidneys) and bone tissue. Due to the lower Cd transportation into the sites of its toxic action, including bone tissue, and faster elimination from the organism of the absorbed metal, the amounts of $\mathrm{Cd}$ at the sites of its action, including oxidative action, were lower, and thus the effects of its toxicity were less intensified or even completely counteracted by AME administration [22]. Since Cd, even at low concentrations, may directly influence bone tissue cell activity and oxidative/antoxidative balance, it seems reasonable to assume that the beneficial impact of AME on the oxidative/antioxidative status of the bone tissue under the higher of the investigated levels of $\mathrm{Cd}$ treatment was, at least to some extent, the result of the lower bone concentration of this metal. Thus, via decreasing $\mathrm{Cd}$ accumulation in the bone and kidneys, AME might provide protection from the direct and/or indirect impact of this xenobiotic (depending on the exposure level) on the skeleton [22, $23,36]$. Numerous correlations noted between $\mathrm{Cd}$ concentration in the bone tissue and the measured markers of the bone oxidative/antioxidative status in the animals receiving, or not, AME under the treatment with this metal confirm the possibility of such a mechanism. The fact that AME administration under exposure to the $1 \mathrm{mg} \mathrm{Cd} / \mathrm{kg}$ diet improved the oxidative/antioxidative bone status without influencing the bone concentration of this metal shows the direct protective impact of this extract's ingredients on the oxidative/antioxidative balance in bone tissue. Because the possible protective impact of AME on the bone tissue under and without exposure to $\mathrm{Cd}$ has not been investigated until now by other authors, a wider discussion of our results is impossible. Moreover, it should be taken into consideration that the improvement of the oxidative/antioxidative status of the serum (reflecting the whole body oxidative/antioxidative status) and bone tissue by AME administration under physiological conditions and exposure to $\mathrm{Cd}$ might be related to the ability of polyphenols to penetrate into tissues (including bone). These compounds have been reported to be present in various organs of rats, including target organs for Cd, such as kidneys and liver [37]; however, their penetration into the bone tissue has not been investigated, but it cannot be excluded. The available data indicating that consumption of polyphenols improves bone turnover and BMD in both human [21] and experimental animals [16,23] confirm the possibility of the direct impact of these compounds on bone status.

We are aware that our study does not allow for explaining the exact mechanisms of the oxidative defense system's involvement in the protective action of the chokeberry extract against Cd-induced disorders in bone metabolism. The next limitation of this study is conducting the experiment only in a female rat model. Because sex hormones influence $\mathrm{Cd}$ metabolism and toxicity, and the female skeleton is more susceptible to the damaging impact of this heavy metal [38-40], the conclusion on the beneficial impact of AME on bone oxidative/antioxidative status and the involvement of the extract's antioxidative potential in the mechanisms of osteoprotective influence refers only to the female skeleton.
In summary, it has been revealed for the first time that consumption of the chokeberry extract under low and moderate chronic exposure to $\mathrm{Cd}$ exerts an osteoprotective impact via mediating the oxidative defense system and preventing oxidative modifications of protein, lipid, and DNA in the bone tissue. This is the most important and practically useful finding of the present study. Based on the results, it seems possible that the chokeberry may be a promising natural plant origin product for preventing oxidative stress-related bone damage in women chronically exposed to $\mathrm{Cd}$. The results support the potential of $A$. melanocarpa berries, recently reported by us $[6,22,23]$, to be an effective natural product for protection against Cd toxicity. However, the possible prophylactic use of the chokeberry under environmental exposure to $\mathrm{Cd}$ needs further investigation involving epidemiological studies in both men and women.

\section{Materials and Methods}

$\nabla$

\section{Chemicals}

All chemicals and reagents were of the highest grade purity or analytical purity. Most of the assays were performed with the use of commercial kits. Ultrapure water was used in all measurements.

\section{Cadmium diets}

Homogeneous in terms of Cd content diets, containing 1 and $5 \mathrm{mg} \mathrm{Cd} / \mathrm{kg}$, were prepared by Label Food "Morawski" by the addition of cadmium chloride $\left(\mathrm{CdCl}_{2} \times 2 \frac{1}{2} \mathrm{H}_{2} \mathrm{O}\right.$; POCh) into the ingredients of the standard Labofeed $\mathrm{H}$ diet (breeding diet) and Labofeed B diet (maintenance diet) [22]. The mean Cd concentration determined in the diets reached $1.09 \pm 0.13 \mathrm{mg} / \mathrm{kg}$ and $4.92 \pm 0.53 \mathrm{mg} / \mathrm{kg}$, respectively, whereas its concentration in the standard Labofeed diets was $0.0584 \pm 0.0049 \mathrm{mg} / \mathrm{kg}$ (mean $\pm \mathrm{SD}$ ).

\section{Aronia melanocarpa extract}

A certified (Certificate KJ 4/2010) lyophilized AME, containing $65.74 \%$ of polyphenols (18.65\% of anthocyanins), was supplied by Adamed Consumer Healthcare. The polyphenolic profile of A. melanocarpa berries is well known and widely reported [13, $14,18]$; however, the phytochemical profile of AME was estimated (Fig. 1S, Supporting Information) and quantified by us (Table 10S, Supporting Information) [23]. The total polyphenols content in the lyophilized AME and the compounds concentration in its $0.1 \%$ aqueous solution reached $61.24 \pm 0.33 \%$ and $0.612 \pm$ $0.003 \mathrm{mg} / \mathrm{mL}$ (mean $\pm \mathrm{SE}$ ), respectively [23].

According to the producer's declaration and literature data [13, 14], AME also contains other components such as sugar, pectins, sugar alcohols (sorbitol, parasorboside), phytosterols, triterpenes, and carotenoids as well as minerals and vitamins.

\section{Animals}

One hundred and ninety-two young (3-4 weeks old) female Wistar rats [Crl:WI (Han)] purchased from the certified Laboratory Animal House in Brwinów were used. The animals were kept in controlled conventional conditions (temperature $22 \pm 2{ }^{\circ} \mathrm{C}$, relative humidity $50 \pm 10 \%, 12$-h light/dark cycle). They had free access to drinking water and food. Throughout the first three months, all animals were maintained on the Labofeed $\mathrm{H}$ diet and thereafter they received the Labofeed B diet. 


\section{Experimental protocol}

The study was approved by the Local Ethics Committee for Animal Experiments in Bialystok (Poland; approval number 60/ 2009 on 21 September 2009). All procedures with the animals were performed according to the ethical principles and institutional guidelines and International Guide for the Use of Animals in Biomedical Research.

After a five-day acclimatization, the rats were randomly allocated into six experimental groups, each containing 32 animals (mean body weight about $65 \mathrm{~g}$ ). One group received AME alone (AME group), two groups were treated with $\mathrm{Cd}$ alone via the diet containing 1 and $5 \mathrm{mg} \mathrm{Cd} / \mathrm{kg}\left(\mathrm{Cd}_{1}\right.$ and $\mathrm{Cd}_{5}$ groups), and the next two groups received AME during the exposure to $\mathrm{Cd}\left(\mathrm{Cd}_{1}+\mathrm{AME}\right.$ and $\mathrm{Cd}_{5}+$ AME groups) for $3,10,17$, and 24 months. The last group, maintained on redistilled water $(<0.05 \mu \mathrm{g} \mathrm{Cd} / \mathrm{L})$ and standard Labofeed diet (without AME and Cd), served as a control. AME was administered as a $0.1 \%$ aqueous solution of the powdered extract, used as the only drinking fluid. The solution was prepared daily (stable for at least $24 \mathrm{~h}$ ) and contained $<0.05 \mu \mathrm{g}$ $\mathrm{Cd} / \mathrm{L}$. The concentration of the aqueous solution of AME was chosen based on the available literature data $[15,41]$ to reach polyphenol intake markedly higher than the recommended daily consumption, but not too high.

In our study, there was no positive control since, until now, there was no effective chelating therapy for $\mathrm{Cd}$. Moreover, the synthetic compounds used for this purpose are strong chelators of bioelements and, thus, they cannot be administered for long periods [6].

The daily intake of $\mathrm{Cd}$ throughout the 24-month exposure to the 1 and $5 \mathrm{mg} \mathrm{Cd} / \mathrm{kg}$ diets reached 37.50-84.88 $\mu \mathrm{g} / \mathrm{kg}$ b.wt and $196.69-404.76 \mu \mathrm{g} / \mathrm{kg}$ b.wt, respectively, whereas polyphenol intake reached $41.5-104.6 \mathrm{mg} / \mathrm{kg}$ b.wt, irrespective of whether these substances were administered alone or in conjunction [22, 23]. There were no clinical signs of morbidity during the study; however, three cases of spontaneous death (in the AME, $\mathrm{Cd}_{1}$, and $\mathrm{Cd}_{5}$ groups) were noted between the 17 th and 24 th month. The experimental protocol has been presented in detail in our previous reports $[22,23]$. Since females are more vulnerable to $\mathrm{Cd}$ toxicity, including bone damage, than males [38-40], the study was conducted in females.

At termination, the animals were anesthetized with barbiturate (Morbital, $30 \mathrm{mg} / \mathrm{kg}$ b.wt, i.p.) and whole blood was collected by cardiac puncture in tubes with and without anticoagulant (heparin). Next, different organs and tissues, including both femurs and tibias, were dissected. A portion of the whole blood collected without anticoagulant was centrifuged after coagulation and the serum was separated. The bones, after cleaning of the surrounding muscles and tissues, were weighted. The biological material not used immediately was stored frozen at $-70^{\circ} \mathrm{C}$ or $-20^{\circ} \mathrm{C}$ until all measurements were performed.

Samples of the serum and bone slices from the distal femoral epiphysis (trabecular bone region) were used in this study. To evaluate the oxidative/antioxidative bone status, numerous indices of the enzymatic (GPx, GR, SOD, and CAT) and nonenzymatic (GSH and T-SH) antioxidative barrier, TAS (a marker of total antioxidative potential), TOS (a marker of total oxidative status), and concentration of $\mathrm{H}_{2} \mathrm{O}_{2}$ were measured in the bone tissue. TAS and TOS were also determined in the serum, and the OSI (a marker of oxidative stress intensity) was calculated (OSI = TOS/TAS). In order to evaluate the extent of oxidative changes in the bone tissue, sensitive markers of oxidative modifications of protein and DNA, such as PC and 8-OHdG, respectively, as well as LPO and 8-isoP, as markers of lipid peroxidation, were determined.

\section{Analytical procedures}

Preparation of bone tissue homogenates: With the aim of evaluating all indices of the oxidative/reductive bone status, except for 8OHdG, 10\% homogenates of the bone from the distal femoral epiphysis in a cold potassium phosphate buffer ( $50 \mathrm{mM}, \mathrm{pH}=7.4$ ) with the addition of butyl-hydroxytoluene were prepared using a high-performance homogenizer (Ultra-Turrax T25; IKA), as previously reported [24]. Each homogenate was divided into two portions - one was centrifuged (MPW-350R centrifugator, Medical Instruments) at $700 \times g$ for 20 min (for CAT, TAS, TOS, $\mathrm{H}_{2} \mathrm{O}_{2}$, LPO, and PC measurements) and the other at $20000 \times \mathrm{g}$ for $30 \mathrm{~min}$ (for GPx, GR, and SOD) at $4{ }^{\circ} \mathrm{C}$, and the aliquots were collected for measurements [42].

Assays: TAS and TOS were determined with the use of ImAnOx (TAS) ELISA kit and PerOx (TOS) ELISA kit by Immundiagnostik AG. The assay of TAS is based on the reaction of antioxidants present in the analyzed sample with a defined amount of exogenously provided $\mathrm{H}_{2} \mathrm{O}_{2}$ and photometrical determination of the residual $\mathrm{H}_{2} \mathrm{O}_{2}$, while under the assay of TOS, total lipid peroxides are measured in the reaction with peroxidase.

The activities of GPX, GR, and SOD were determined with the use of a Bioxytech GPx-340 kit (OxisResearch), Bioxytech GR-340 kit, and kit by the Cayman Chemical Company, respectively, whereas the CAT assay was performed according to the spectrophotometric method by Aebi [43]. The concentration of GSH was measured using the Bioxytech GSH-400 kit (OxisResearch) and that of T-SH by the modified Ellman's method [44]. $\mathrm{H}_{2} \mathrm{O}_{2}$ was determined according to the method described in the Bioxytech $\mathrm{H}_{2} \mathrm{O}_{2}-560$ kit by Oxis. PCs were determined with the spectrophotometric method based on the reaction of PC with 2,4-dinitrophenylhydrazine [45]. 8-isoP and LPO were assayed using an 8-isoP EIA kit by the Cayman Chemical Company and a Bioxytech LPO-586 kit by Oxis. The concentration of 8-OHdG was determined using an ELISA kit by Percipio Biosciences after DNA isolation from the bone with the use of the Nuclear Extraction Kit by the Cayman Chemical Company.

All assays with the use of commercial kits were performed as described in the manufacturers' instructions, and the measured parameters were adjusted for protein concentration (determined with the use of an EMAPOL kit). Analytical quality of all measurements was checked and is available, together with the main principles of the performed assays (if not described in this section), as Supporting Information.

An automated microplate washer (Thermolabsystems Wellwash 4, Labsystems), Thermo Scientific Multiskan GO spectrophotometer, ELISA universal microplate reader (BIO-TEK INSTRUMENTS INC, ELX 800 ), and Hitachi U-3010 spectrophotometer were employed.

\section{Statistical analysis}

The Statistica 10 package (StatSoft) was used to analyze the data. A one-way analysis of variance (Anova) with Duncan's multiple range post hoc test was conducted for comparisons between individual groups and to determine which two means differed statistically significantly $(\mathrm{p}<0.05)$. To discern the possible interactions between Cd and AME, a two-way analysis of variance (ANOVA/MANOVA, test $\mathrm{F}$ ) was conducted. $\mathrm{F}$ values having $\mathrm{p}<0.05$ were considered statistically significant. Spearman rank 
correlation analysis was performed to investigate mutual relationships among variables.

\section{Supporting information}

Details on the effects of AME and Cd, the UPLC polyphenolic profile of the extract, and the main principles of the assays of the indices of the oxidative/antioxidative status and analytical quality of these measurements are available as Supporting Information.

\section{Acknowledgements}

This study was financially supported in part by a grant (No. N N405 051140) from the National Science Centre (Poland) and Medical University of Bialystok (Poland). The study was conducted with the use of equipment purchased by the Medical University of Bialystok as part of the OP DEP 2007-2013, Priority Axis I.3, contract No. POPW.01.03.00-20-001/12.

\section{Conflict of Interest}

$\nabla$

The authors declare that there are no conflicts of interest.

\section{References}

1 Satarug S, Garrett SH, Sens MA, Sens DA. Cadmium, environmental exposure, and health outcomes. Environ Health Perspect 2010; 118: $182-190$

2 Nawrot TS, Staessen JA, Roels HA, Munters E, Cuypers A, Richart T, Ruttens A, Smeets K, Clijsters H, Vangronsveld J. Cadmium exposure in the population: from health risks to strategies of prevention. Biometals 2010; 23: 769-782

3 Prabu MS, Shagirtha K, Renugadevi J. Naringenin in combination with vitamins $C$ and $E$ potentially protects oxidative stress-mediated hepatic injury in cadmium-intoxicated rats. J Nutr Sci Vitaminol 2011; 57: $177-185$

4 Flora SJS, Shrivastava R, Mittal M. Chemistry and pharmacological properties of some natural and synthetic antioxidants for heavy metal toxicity. Curr Med Chem 2013; 20: 4540-4574

5 Bashir N, Manoharan V, Prabu MS. Protective role of grape seed proanthocyanidins against cadmium induced hepatic dysfunction in rats. Toxicol Res 2014; 3: 131-141

6 Brzóska MM, Borowska S, Tomczyk M. Antioxidants as a potential preventive and therapeutic strategy for cadmium. Curr Drug Targets, advance online publication 6 May 2015; DOI: 10.2174/ 1389450116666150506114336

7 García-Niňo WR, Pedraza-Chaverrí J. Protective effect of curcumin against heavy metals-induced liver damage. Food Chem Toxicol 2014; 69: 182-201

8 Pari L, Shagirtha $K$. Hesperetin protects against oxidative stress related hepatic dysfunction by cadmium in rats. Exp Toxicol Pathol 2012; 64: 513-520

9 Renugadevi J, Prabu MS. Cadmium-induced hepatotoxicity in rats and the protective effect of naringenin. Exp Toxicol Pathol 2010; 62: 171181

10 Åkesson A, Barregard L, Bergdahl IA, Nordberg GF, Nordberg M, Skerfving $S$. Non-renal effects and the risk assessment of environmental cadmium exposure. Environ Health Perspect 2014; 122: 431-438

11 Chen X, Gan C, Zhu G, Jin T. Benchmark dose for estimation of cadmium reference level for osteoporosis in a Chinese female population. Food Chem Toxicol 2013; 55: 592-595

12 Sommar JN, Pettersson-Kymmer U, Lundh T, Svensson O, Hallmans G, Bergdahl IA. Hip fracture risk and cadmium in erythrocytes: a nested case-control study with prospectively collected samples. Calcif Tissue Int 2014; 94: 183-190

13 Kokotkiewicz A, Jaremicz Z, Łuczkiewicz M. Aronia plants: a review of traditional use, biological activities, and perspectives for modern medicine. J Med Food 2010; 13: 255-269
14 Kulling SE, Rawel HM. Chokeberry (Aronia melanocarpa) - A review on the characteristic components and potential health effects. Planta Med 2008; 74: 1625-1634

15 Kowalczyk E, Kopff A, Fijalkowski P, Kopff M, Niedworok J, Blaszczyk J, Kedziora J, Tyslerewicz P. Effect of anthocyanins on selected biochemical parameters in rats exposed to cadmium. Acta Biochim Pol 2003; 50: 543-548

16 Choi JH, Rhee IK, Park KY, Park KY, Kim JK, Rhee SJ. Action of green tea catechin on bone metabolic disorder in chronic cadmium-poisoned rats. Life Sci 2003; 73: 1479-1489

17 Paik MK, Lee HO, Chung HS, Yang SO, Kim JH, Om AS. Genistein may prevent cadmium-induced bone loss in ovariectomized rats. J Med Food 2003; 6: 337-343

18 Denev PN, Kratchanov CG, Ciz M, Lojek A, Kratchanova MG. Bioavailability and antioxidant activity of black chokeberry (Aronia melanocarpa) polyphenols: in vitro and in vivo evidences and possible mechanisms of action: a review. Compr Rev Food Sci Food Saf 2012; 11: 471-489

19 Olas B, Wachowicz B, Nowak P, Kedzierska M, Tomczak A, Stochmal A, Oleszek W, Jeziorski A, Piekarski J. Studies on antioxidant properties of polyphenol-rich extract from berries of Aronia melanocarpa in blood platelets. J Physiol Pharmacol 2008; 59: 823-835

20 Bräunlich M, Slimestad R, Wangensteen H, Brede C, Malterud KE, Barsett $H$. Extracts, anthocyanins and procyanidins from Aronia melanocarpa as radical scavengers and enzyme inhibitors. Nutrients 2013; 5: 663678

21 Hubert PA, Lee SG, Lee SK, Chun OK. Dietary polyphenols, berries, and age-related bone loss: a review based on human, animal, and cell studies. Antioxidants 2014; 3: 144-158

22 Brzóska MM, Galazyn-Sidorczuk M, Jurczuk M, Tomczyk M. Protective effect of Aronia melanocarpa polyphenols on cadmium accumulation in the body: a study in a rat model of human exposure to this metal. Curr Drug Targets 2015; 16: 1470-1487

23 Brzóska MM, Rogalska J, Galażyn-Sidorczuk M, Jurczuk M, Roszczenko A, Tomczyk M. Protective effect of Aronia melanocarpa polyphenols against cadmium-induced disorders in bone metabolism: a study in a rat model of lifetime human exposure to this heavy metal. Chem Biol Interact 2015; 229: 132-146

24 Brzóska MM, Rogalska J, Kupraszewicz E. The involvement of oxidative stress in the mechanisms of damaging cadmium action in bone tissue: a study in a rat model of moderate and relatively high human exposure. Toxicol Appl Pharmacol 2011; 250: 327-335

25 Wauquier F, Leotoing L, Coxam V, Guicheux J, Wittrant Y. Oxidative stress in bone remodelling and disease. Trends Mol Med 2009; 15: 468-477

26 Smith SS, Reyes JR, Arbon KS, Harvey WA, Hunt LM, Heggland SJ. Cadmium-induced decrease in RUNX2 mRNA expression and recovery by the antioxidant $\mathrm{N}$-acetylcysteine (NAC) in the human osteoblast-like cell line, Saos-2. Toxicol In Vitro 2009; 23: 60-66

27 Brzóska MM, Rogalska J. Protective effect of zinc supplementation against cadmium-induced oxidative stress and the RANK/RANKL/OPG system imbalance in the bone tissue of rats. Toxicol Appl Pharmacol 2013; 272: 208-220

28 Matović V, Buha A, Đukić-Ćosić D, Bulat Z. Insight into the oxidative stress induced by lead and/or cadmium in blood, liver and kidneys. Food Chem Toxicol 2015; 78: 130-140

29 Dai F, Chen WF, Zhou B. Antioxidant synergism of green tea polyphenols with alpha-tocopherol and L-ascorbic acid in SDS micelles. Biochimie 2008; 90: 1499-1505

30 Graversen HB, Becker EM, Skibsted LH, Andersen ML. Antioxidant synergism between fruit juice and $\alpha$-tocopherol. A comparison between high phenolic black chokeberry (Aronia melanocarpa) and high ascorbic blackcurrant (Ribes nigrum). Eur Food Res Technol 2008; 226: 737743

31 Kwak SC, Lee C, Kim JY, Oh HM, So HS, Lee MS, Rho MC, Oh J. Chlorogenic acid inhibits osteoclast differentiation and bone resorption by downregulation of receptor activator of nuclear factor kappa-B ligand-induced nuclear factor of activated T cells $\mathrm{c} 1$ expression. Biol Pharm Bull 2013; 36: 1779-1786

32 Derakhshanian H, Djalali M, Djazayery A, Nourijelyani K, Ghadbeigi S, Pishva H, Saedisomeolia A, Bahremand A, Dehpour AR. Quercetin prevents experimental glucocorticoid-induced osteoporosis: a comparative study with alendronate. Can J Physiol Pharmacol 2013; 91: 380385

33 Yamaguchi M, Weitzmann MN. Zinc stimulates osteoblastogenesis and suppresses osteoclastogenesis by antagonizing NF- $k \mathrm{~B}$ activation. Mol Cell Biochem 2011; 355: 179-186 
34 Hadley KB, Newman SM, Hunt JR. Dietary zinc reduces osteoclast resorption activities and increases markers of osteoblast differentiation, matrix maturation, and mineralization in the long bones of growing rats. J Nutr Biochem 2010; 21: 297-303

35 Sanchez C, Horcajada MN, Membrez Scalfo F, Ameye L, Offord E, Henrotin $Y$. Carnosol inhibits pro-inflammatory and catabolic mediators of cartilage breakdown in human osteoarthritic chondrocytes and mediates cross-talk between subchondral bone osteoblasts and chondrocytes. PLoS One 2015; 10: e0136118

36 Bhattacharyya MH. Cadmium osteotoxicity in experimental animals: mechanisms and relationship to human exposure. Toxicol Appl Pharmacol 2009; 238: 258-265

37 Kirakosyan A, Seymour EM, Wolforth J, McNish R, Kaufman PB, Bolling SF Tissue bioavailability of anthocyanins from whole tart cherry in healthy rats. Food Chem 2015; 171: 26-31

38 Vahter M, Akesson A, Lidén C, Ceccatelli S, Berglund M. Gender differences in the disposition and toxicity of metals. Environ Res 2007; 104: 85-95
39 Brzóska MM, Moniuszko-Jakoniuk J. Bone metabolism of male rats chronically exposed to cadmium. Toxicol Appl Pharmacol 2005; 207: 195-211

40 Brzóska MM, Moniuszko-Jakoniuk J. Disorders in bone metabolism of female rats chronically exposed to cadmium. Toxicol Appl Pharmacol 2005; 202: 68-83

41 Hellström JK, Shikov AN, Makarova MN, Pihlanto AM, Pozharitskaya ON, Ryhänen EL, Kivijärvi, Makarov VG, Mattila PH. Blood pressure-lowering properties of chokeberry (Aronia mitchurinii, var. Viking). J Funct Foods 2010; 2: 163-169

42 Sahin E, Gümüşlü S. Immobilization stress in rat tissues: alterations in protein oxidation, lipid peroxidation and antioxidant defense system. Comp Biochem Physiol C Toxicol Pharmacol 2007; 144: 342-347

43 Aebi HE. Catalase in vitro. Methods Enzymol 1984; 105: 121-126

44 Ellman GL. Tissue sulfhydryl groups. Arch Biochem Biophys 1959; 82: 70-77

45 Reznick AZ, Packer L. Oxidative damage to proteins: spectrophotometric method for carbonyl assay. Methods Enzymol 1994; 233: 357-363 